\title{
College English Teaching Design and Practice Based on Cross-cultural Theory
}

\author{
http://dx.doi.org/10.3991/ijet.v11i08.6051 \\ Xin Zhao*, Shuang Gu, Shanshan Yu, Mingli Gao \\ North China University of Science and Technology, Tangshan, Hebei, China
}

\begin{abstract}
The theoretical bases for the thesis are crosscultural foreign language education theory, systemic education theory and multimedia-assisted English teaching theory. At first, the thesis summarizes and analyzes every unit involving cultural knowledge in College English textbook Oxford English used in Shanghai at present, demonstrating the feasibility of culture teaching in the elementary stage of College English. Then based on systemic teaching theories, the thesis analyzes teaching aim, teaching demand, teaching environment, teaching content, teaching strategies, evaluative strategies and implementation of culture teaching. Next, the thesis designs specific courses to match daily teaching activities by way of collecting culture teaching materials, designing culture teaching content and relevant teaching strategies. When designing specific courses, I take advice from experts and teachers on the front, develop three teaching cases and use courseware for teaching practice.
\end{abstract}

Index Terms-College English teaching; cross-cultural theory; teaching design and practice; teaching evaluation.

\section{INTRODUCTION}

Recently, culture teaching in foreign languages has developed by leaps and bounds in educational field. Many experts, scholars, educational institutes and teachers on the front are willing to attempt to accept such culture teaching pattern. However, after investigation, I find that most culture teaching research is confined to university because some educational researchers think it is not necessary for culture teaching in elementary stage. They also think that College English learning is a basic stage in which they need focus on accuracy of pronunciation, tone, grammar and accumulation of vocabulary. Others hold that complexity of culture teaching makes it difficult to teach in practice. Although many educators in elementary stage think highly of culture teaching, recent research has been still confined to theory [1]. Due to difficulties in culture teaching practice in elementary stage, the thesis presents some problems of culture teaching in College English and gives some preliminary solutions in the hope of sharing and seeking for more solutions.

\section{DEMAND ANALYSIS OF COLLEGE ENGLISH IN CROSS-CULTURAL TEACHING}

\section{A. Demand of growing social exchanges}

With the development of society, there are more and more international communications, especially in English. Therefore, adding some reasonable and relevant cultural knowledge in College English will contribute to communicating in natural and native-like English.

\section{B. Demand of education for international understanding}

Education for international understanding is a new educational idea which recognizes cultural diversity and emphasizes understanding, tolerance and respect in crosscultural exchange. In terms of education, the idea emphasizes cultural diversity such as cognition, emotion, will and behavior for the purpose of better exchange and cooperation. Since the idea of education for international understanding is more scientific, many educational institutes begin to introduce it at present. In essence, education for international understanding belongs to cross-cultural education field, so we can call it education for cross-cultural understanding. Because cross-cultural education not only focuses on cultural education among nations and regions but also that of different classes, areas and sexes[2]. Obviously, cross-cultural education will contribute to development of education for international understanding if conducted in elementary education stage.

\section{Demand of relevant course standard}

The nature of English teaching is a combination of knowledge and humanity, and a combination of tool and practice. What's more, the first item of curriculum idea is: "improving students' social communicative competence in the background of multi-culture embodies a demand of the Age and English curriculum happens to provide an important learning resource for that (middle and primary school teaching material reform committee in Shanghai, 2005)". In this case, students will learn more about communication on the condition of putting English in the social development.

\section{CRoss-Cultural Teaching System Design}

\section{A. Learners' Feature in Middle School}

(1) General feature analysis

There are many advantageous factors for learners in middle school in terms of culture teaching. Firstly, there is a rapid development of logic for learners in middle school, especially abstract logic, which is helpful for understanding certain cultural phenomena. Secondly, they have steadier attention than they do in primary school, which embodies in keeping paying attention to their interested things for a relative long time [4]. Thirdly, they have independent thinking ability which helps in identifying cultural phenomena. Fourthly, they have more interest and enlarged interpersonal demand, which also contributes to cultural communication. Fifthly, middle school students tend to explore, which means they prefer to acquire cul- 
PAPER

College English Teaching Design and Practice Based on Cross-Cultural Theory

tural knowledge and skills by themselves or cooperating with others.

(2) Learners' motivation analysis

My investigation of interview and questionnaire shows that students are motivated to learn western culture. Firstly, students are interested in cultural phenomena in English learning [5]. To some degree, they have self-developing consciousness and would like to accept learning content and teaching methods related to cultivating cultural communication skills.

TABLE I.

THE OXFORD ENGLISH CULTURAL KNOWLEDGE TEACHING MATERIAL ANALYSIS-OXFORD 7A

\begin{tabular}{|l|l|l|}
\hline \multirow{4}{*}{ Relationships } & Unit 1 Relatives in Beijing & interpersonal relationships \\
\cline { 2 - 2 } & Unit 2 our animal friends & entertainment \\
\cline { 2 - 2 } My neighborhood & Unit 3 Friends from other countries & interpersonal relationships \\
\hline \multirow{4}{*}{ Diet and health } & Unit 4 Jobs people do & the social responsibility \\
\cline { 2 - 2 } & Unit 5 Choosing a new flat & \\
\cline { 2 - 2 } & Unit 6 Different places & Ideological education \\
\cline { 2 - 2 } & Unit 7 Signs around us & necessary cultural life \\
\hline & Unit 8 Growing healthy, growing strong & \\
\cline { 2 - 3 } & Unit 9 International Food Festival & \\
\cline { 2 - 3 } & Unit 10 A birthday party & life \\
\cline { 2 - 3 } & Unit 11 My food project & \\
\hline
\end{tabular}

TABLE II.

THE OXFORD ENGLISH CULTURAL KNOWLEDGE TEACHING MATERIAL ANALYSIS—OXFORD 7B

\begin{tabular}{|c|c|c|}
\hline \multirow{3}{*}{ Garden city and its neighbors } & Unit 1 Writing a travel guide & \multirow{4}{*}{ entertainment } \\
\hline & Unit 2 Going to see a film & \\
\hline & Unit 3 A visit to garden city & \\
\hline \multirow{4}{*}{ Better future } & Unit 4 Let's go shopping & \\
\hline & Unit 5 What can we learn from others? & Social values \\
\hline & Unit 6 Hard work for a better life & Life values \\
\hline & Unit 7 In the future & Life values \\
\hline \multirow{3}{*}{ The natural elements } & Unit 8 A more enjoyable school life & Social values \\
\hline & Unit 9 The wind is blowing & \\
\hline & Unit 10 Water festival & Sense of time and space \\
\hline
\end{tabular}

TABLE III

THE OXFORD ENGLISH CULTURAL KNOWLEDGE TEACHING MATERIAL ANALYSIS—OXFORD 8A

\begin{tabular}{|c|l|l|}
\hline \multirow{2}{*}{ My life } & Unit 1 Pen friends & \multirow{2}{*}{ Ideological education } \\
\cline { 2 - 2 } & Unit 2 Work and play & \\
\cline { 2 - 2 } & Unit 3 Trouble & aesthetic \\
\hline \multirow{2}{*}{ Amazing things } & Unit 4 Numbers & Ideological education \\
\cline { 2 - 3 } & Unit 5 Encyclopedias & \\
\hline \multirow{2}{*}{ Science fiction } & Unit 6 Nobody wins (1) & \\
\cline { 2 - 3 } & Unit 7 Nobody wins (2) & \\
\hline
\end{tabular}

TABLE IV.

THE OXFORD ENGLISH CULTURAL KNOWLEDGE TEACHING MATERIAL ANALYSIS—OXFORD 8B

\begin{tabular}{|c|l|l|}
\hline \multirow{2}{*}{ Nature and environment } & Unit 1 Trees & \multirow{2}{*}{ Ideological education } \\
\cline { 2 - 2 } & Unit 2 Water & \\
\cline { 2 - 3 } & Unit 3 Electricity & Ideological education \\
\hline \multirow{2}{*}{ Mass media } & Unit 4 Newspaper & \multirow{2}{*}{ entertainment } \\
\cline { 2 - 3 } & Unit 5 Magazine articles & \\
\hline \multirow{2}{*}{ Leisure time } & Unit 6 Travel & entertainment \\
\cline { 2 - 3 } & Unit 7 Poems &
\end{tabular}


PAPER

College English Teaching Design and Practice Based on Cross-Cultural Theory

TABLE V. THE OXFORD ENGLISH CULTURAL KNOWLEDGE TEACHING MATERIAL ANALYSIS-OXFORD 9A

\begin{tabular}{|c|l|l|}
\hline \multirow{2}{*}{ Myths, traditions and opinions } & Unit 1 Ancient Greece & Ideological education \\
\cline { 2 - 3 } & Unit 2 Traditional skills & Social values \\
\cline { 2 - 3 } & Unit 3 Pets & entertainment \\
\hline \multirow{2}{*}{ Computers vs humans } & Unit 4 Computers & \\
\cline { 2 - 3 } & Unit 5 The human brain & entertainment \\
\hline \multirow{2}{*}{ Fighting crime } & Unit 6 Detectives & \\
\cline { 2 - 3 } & Unit 7 Escaping from kidnappers & \\
\hline
\end{tabular}

TABLE VI.

THE OXFORD ENGLISH CULTURAL KNOWLEDGE TEACHING MATERIAL ANALYSIS-AXFORD 9B

\begin{tabular}{|c|l|l|}
\hline \multirow{2}{*}{ Environment and life } & Unit 1 Ancient Greece & \multirow{2}{*}{ Natural conception } \\
\cline { 2 - 2 } & Unit 2 Traditional skills & \multirow{3}{*}{ entertainment } \\
\cline { 2 - 3 } & Unit 3 Pets & \\
\hline \multirow{2}{*}{ Recreation and entertainment } & Unit 4 Detectives & Unit 5 Escaping from kidnappers \\
\cline { 2 - 3 } & &
\end{tabular}

But they lack consciousness of related cultures to which teachers need draw their attention. Secondly, there are many opportunities for students to communicate in English in their daily life, which sometimes will cause cultural conflicts. Therefore, they have real demands for learning culture [6]. Thirdly, teachers will remind them consciously in the process of teaching before investigation so that students can have a better understanding of some cultural conflicts.

\section{B. Cross-cultural Teaching Content in College English}

English textbook of middle school used in Shanghai includes many cultural content, such as English etymology and variation involving countries like Britain, America, France, Canada and Australia, etc., which shows that culture teaching has been emphasized in theory. Next, I will display relevant content involving cultural knowledge in Oxford English textbook used in Shanghai at present, as shown in Table 1-6.

\section{Cross-cultural Teaching Strategy Analysis in College English}

(1) Cross-cultural teaching strategy in vocabulary

There is lots of cultural information in vocabulary, which reflects different values of speakers. Thus, we should focus more on historical origin or cultural connotation except word meaning and usage. This teaching way not only arouses students' interest but also combines vocabulary teaching with culture teaching. For instance, the word "holiday" derives from Genesis "On the seventh day God finished his work. God blessed the seventh day and made it holy".

(2) Cross-cultural teaching strategy in reading

Some people think the approach of combining reading teaching with culture teaching is to choose those reading materials involving cultural content. But the final purpose of the approach is to improve students' discourse comprehension ability without taking real cultural functions into consideration. To this end, we should turn our attention to reading content by means of designing pre-reading and post-reading tasks. For example, before students start to read a passage of American food culture, teachers should ask some questions about Chinese food culture and ask them to compare American food culture with Chinese food culture. Teachers can guide them to make such comparisons after reading, during which some grammars can be taught.

(1) Cross-cultural teaching strategy in listening and speaking

Listening and speaking activities can help students have a real experience of cross-cultural communication. While many listening and speaking materials are not systemic $\square$ only individual paragraphs, which easily make students confused. As a result, they are strange to real or natural listening materials. Therefore, listening materials in culture teaching should have the following four features: authentic; representative to reflect different cultural aspects in target language and native language; systemic to combine language teaching with culture teaching for the purpose of "half the work with double results"; and suitable by considering students' listening ability in the selection of listening materials. For example, choosing what they can understand and express, as shown in Figure 1.

(2) Cross-cultural teaching strategy in writing

Middle school students already have writing ability and we should keep in mind that we have to consider cultural context, or it will lead to Clingfish. Generally speaking, students in basic educational stage often write a narration closely related to their daily life and another writing type is document writing like letter and notice. Both can combine with culture teaching. For narrative writing, we should pay attention to culturally practical experience. For example, when teaching the theme of "school life", teachers, through reading or audio-visual materials, let students know a day of school life of American peers and remind them of the difference between them. Then, in the process of writing, teachers teach them to correct language expression in order to combine culture teaching and language teaching, as shown in Figure 2.

There are also a great deal of cultural information on format, expression, structure and content in terms of document writing. For instance, firstly, there is a difference of address format between western counties that are from small to large in size and China that is on the contrary; secondly, Chinese people prefer to add mane and date in the end of letter while western people prefer to add them on letterhead; thirdly, when writing e-mail, western people don't leave a blank in every paragraph while Chinese 
people like leaving two blank spaces, as shown in Figure 3. In fact, culture is not invariable for it will become more scientific and convenient. A case in point is that many Chinese write e-mails in western way now.

\section{Cross College English Teaching System Design BASED ON MULTIMEDIA}

\section{A. Teaching Method}

Multimedia provides teachers and students with rich, vivid and easily understandable teaching conditions. Vivid pictures and bright colors make it easier for students to understand knowledge. This kind of teaching is equipped with PPT that is designed by multimedia teaching principle. Certainly, blackboard can't be totally replaced by multimedia and overuse of multimedia will exert adverse teaching effects. Therefore, we should rationally utilize PPT to have a good teaching effect, as shown in Figure 4.

(1) Presenting teaching content through teacher's oral teaching

Teacher's oral teaching, as an old method, still plays an important role. A refined class design with various teaching methods like situated learning and cooperative learning will make a difference. We use many teaching strategies of oral teaching in the process of the experiment, as shown in Figure 5.

Presenting teaching content via sound and image

Multimedia provides vivid teaching methods with the help of videos and audios. As we all know, auditory and visual senses are important ways of acquiring knowledge, information and language. A large amount of drills like that will be helpful for their language sense. What's more, making use of audios and videos will contribute to vivid understanding in the process of teaching cultural knowledge. For example, when involving "How can we get information" in 8BM2 Mass Media of the experiment, the teacher plays an audio and displays pictures for students to have a visual understanding of what they have learnt.

(2) Presenting teaching content through body language

Body language is a voiceless language that outputs information by body or body gesture on visual organ of receiver to form one expression as a "language". It can be said that every word and gesture will make a deep impression on students. Thus the whole experimental process pays much attention to body language.

\section{Brief introduction of Film \& Cultures}

The history of film has been over a hundred years, from the latter part of the 19 th century to the present day. Motion pictures has gradually developed into one of the most important tools of communication and entertainment. Films have had a substantial impact on the arts, technology, and politics.

\section{- History of film, Wikipedis}

Figure 1. Applying Oral Teaching Strategy

\section{Means to get information:}

\section{How can we get information?}

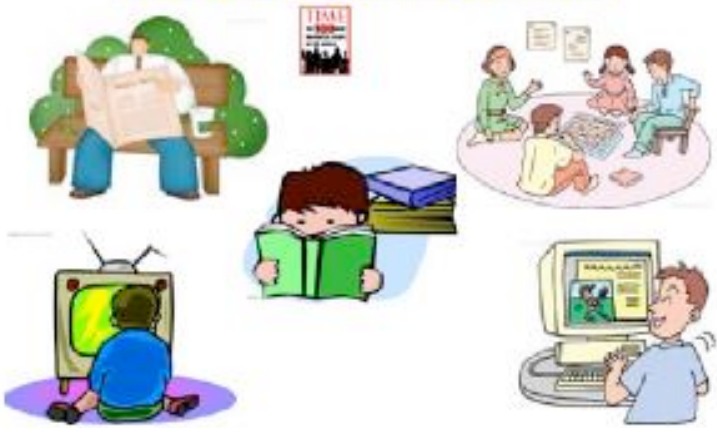

Figure 2. Applying Presented Audio-visual Teaching Content

- Why did Datong lie for his father?

- Do you think it is good for Datong's doing?

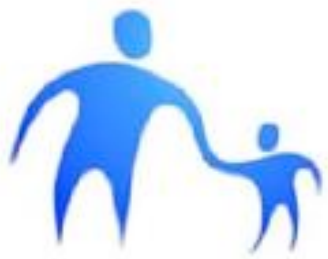

Figure 3. Applying Teaching Strategy of Open Questions

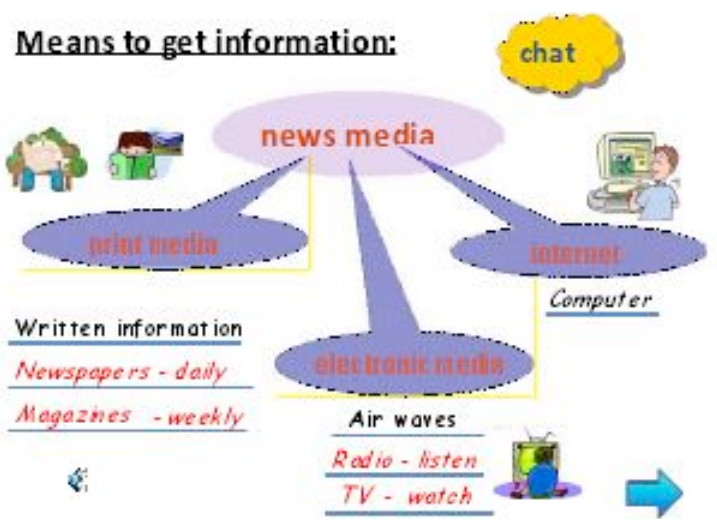

Figure 4. Applying Time Management Strategy

\section{Which section do you like?}

news reports

- stock exchange report

- letters to the editor

- advertisements

sports news
- TV guide

- cartoons

- comic strips

- editorials

- features
OR others?

Figure 5. The application of class discussion teaching strategy 


\section{B. Strategies for Teaching Activity}

\section{(1) More suspense}

Asking questions can stimulate their motivation and enthusiasm. Besides, progressive suspense will make class more smooth and attractive. But the most important thing is to analyze textbooks comprehensively and design reasonable questions according to students' features. Helping students know cultural difference and enlarge their knowledge in a natural way in the process of seeking for answers. We use more questions in Unit 2 Going to See a Film.

\section{(2) Open questions}

Appropriate open questions will have a good teaching effect. On one hand, students can fully express their ideas, which show their initiatives, on the other hand, they will improve students' ability of analyzing and solving problems. Therefore, we should ask more open questions to help students think, analyze and seek for answers for questions. For example, we use open questions like "Why did Datong lie for his father? Do you think it is good for Datong's doing?" in Unit 2 Going to See a Film.

(3) Classroom discussion

There has been much research on strategies related to self-exploration teaching in recent years, which emphasizes the importance of classroom discussion. Selfexploration teaching is a teaching method in which students explore and build up their knowledge via selflearning and cooperative discussion based on students' preview and teacher's elicitation and guidance. The teaching method cultivates students' such abilities as finding and solving problems, innovation and practice. Selfexploration teaching strategies indeed play a role in debatable culture teaching. There are many discussions designed for students in the experiment like strategies in 8BM2 Mass Media, as shown in Figure 6.

\section{CONCLUSION}

The theoretical bases for the thesis are cross-cultural foreign language education theory, systemic education theory and multimedia-assisted English teaching theory. At first, the thesis summarizes and analyzes every unit involving cultural knowledge in College English textbook Oxford English used in Shanghai at present, demonstrating the feasibility of culture teaching in elementary stage of College English. Then based on systemic teaching theories, the thesis analyzes teaching aim, teaching demand, teaching environment, teaching content, teaching strategies, evaluative strategies and implementation of culture teaching. Next, the thesis designs specific courses to match daily teaching activities by way of collecting culture teaching materials, designing culture teaching content and relevant teaching strategies. When designing specific courses, I take advice from experts and teachers on the front, develop three teaching cases and use courseware for teaching practice.

Research methods of the experiment are classroom observation, interview and questionnaire, etc. At first, middle school students have a strong demand for learning culture and the school where the experiment was carried out shows its support for English culture teaching. Then the results of the practical teaching show: firstly, the research helps students broaden their cultural horizon and improve their ability of understanding different cultures; secondly, the teaching design, to some degree, arouses

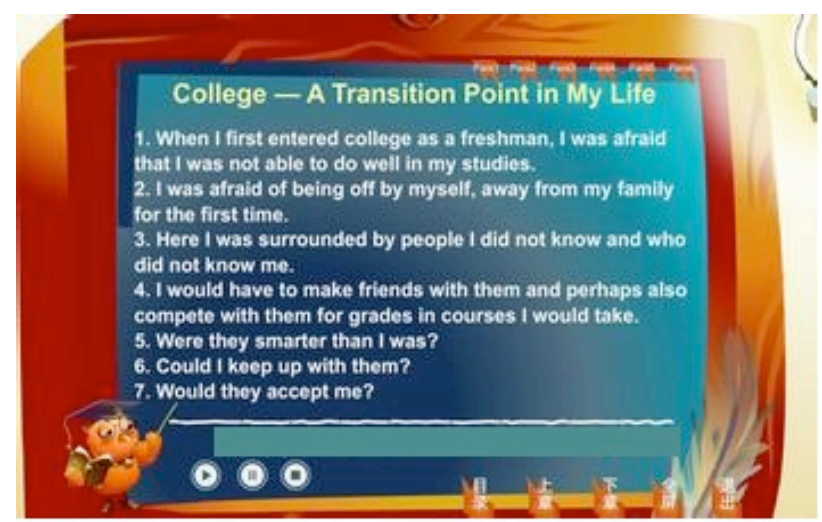

Figure 6. The application of class discussion teaching strategy

students' learning interest, enhances their learning motivation and trains their ability of cooperation; thirdly, the teaching methods used in the experiment, to some degree, have improved teaching efficiency; fourthly, the teaching design, in the long run, contributes to various thinking modes and tolerant attitudes of students.

\section{REFERENCES}

[1] N. Brooks, "Teaching culture in the foreign language classroom," Foreign Language Annals, Vol. 1, pp.204-217, May 1996.

[2] E. Betty, "Constructivist Education and Middle Level Curriculum," Curriculum Perspectives, Vol. 14,pp. 32-33, August 1994.

[3] F. Tamburini, "A multimedia framework for second language teaching inself-access environments," Computer $\square$ Education, vol.12, pp. 137-149, February 1999.

[4] G. Tenenbaum, S. Naidu, O. Jegede, "Jon Austin Constructivist pedagogy in conventional on campus and distance learning practice: an exploratory investigation," Learning and Instruction, vol.11, pp. 87-111, June 2001.

[5] D.H. Jonassen, "do we need a new philosophical paradigm," Educational Technology Research and Development, vol.39, pp.514, June 1991

[6] J. Joseph, E.Darlene, C. Todd, “A social constructivist approach to computer-mediated instruction," Computer $\square$ Education, vol. 38, pp. 221-231, February 2002.

[7] W. Mark, "Computer-mediated collaborative learning: Theory and practice," Modern Language Journal, vol. 81, pp. 470-478, August 1997.

[8] M. Warschauer, D. Healey, "Computers and language learning: An Overview," Language Teaching, vol.31, pp. 102-113, May 1998.

[9] R. Yager, "The Constructivist Learning Model: Towards Real Reform in Science Education," The Science Teacher, vol. 58, pp. 52-57, July 1991.

[10] X. Tang, "Integrating computer technologies into College English Teaching in China," 2010 International Conference on E-Health Networking, Digital Ecosystems and Technologies, EDT 2010, 371-374.

[11] C. Barbaranelli, L. Petitta, T.M. Proust, "Does safety climate predict safety performance in Italy and the USA? Cross-cultural validation of a theoretical model of safety climate," Accident Analysis and Prevention, Vol. 77, pp. 35-44, April 2015.

[12] V. Evers, "Cross-cultural applicability of user evaluation methods: A case study amongst Japanese," North-American, English and Dutch users, Conference on Human Factors in Computing Systems - Proceedings, 2002, pp. 740-741.

[13] X. Chen, "Application of Computer Aided Instruction (CAI) in English teaching for non-English-major postgraduates based on constructivism," Advances in Intelligent and Soft Computing, Vol. 140, pp. 205-210, April 2012.

[14] Y. Chen, "The application of multimedia computer assisted language learning in English teaching," Advanced Materials Research, Vol. 9, pp. 4634-4637. May 2014. 
[15] Y. Wang, "Research on human-computer interaction of English teaching at local area network," ICCASM 2010-2010 International Conference on Computer Application and System Modeling, Vol. 2, pp. 2718-2722, May 2010.

[16] Q.H. Yang, "Research of college English teaching based on computer network technology," Lecture Notes in Electrical Engineering, Vol. 206, pp.375-382, June 2013.

[17] F. Zhang, M. You, "Constructivism computer-assisted instruction model for college English study," Communications in Computer and Information Science, Vol. 233, pp. 200-206, February 2011.

[18] F. Zhang, "Computer aided design of Chinese college English teaching materials based on COCA corpus," Applied Mechanics and Materials, Vol. 59, pp. 916-919, June 2014.

[19] L. Zhang, "Analysis on English value and the effect of computer language," IT Transactions on Engineering Sciences, Vol. 87, pp. 966-970, April 2014.

[20] S. Harnad, "The fourth revolution in the means of production and Knowledge," Public-Access Computer Systems Review, vol. 2, pp. 123-129, May 1991.

[21] J. Hsu, C. Chapelle, "What are they and do students explore," Journal of Educational Computing Research, vol. 9, pp. 1-15, August 1993.

[22] H.S. Jen, L.H. Fang, "Communicative Language Teaching in a Multimedia Language Lab," The Internet TESL Journal, Vol. 2, pp. 24-36, July 2000.

\section{AUTHORS}

Xin Zhao, She received her master's degree in foreign language and applied linguistics in 2011 from Yanshan University. Now she is a lecturer in Jitang College of North China University of Science and Technology. Her current research interests include intercultural communi- cation and college English teaching. (email: dongdonglove526@163.com)

Shuang Gu, She received her master's degree in Linguistics and Applied Linguistics in 2009 from North China University of science and Technology. Now she is a lecturer in North China University of Science and Technology. Her current research interests include intercultural communication and college English teaching. (email: 15133539@qq.com).

Shanshan $\mathbf{Y u}$, She received her master's degree in foreign language literature in 2009 from Dalian University. Now she is a lecturer in North China University of Science and Technology. Her current research interests include intercultural communication and college English teaching. (email: shanshanyu123@163.com).

Mingli Gao, She received her master's degree in foreign languages and literatures in 2015 from North China University of Science and Technology. Now she is an assistant in Jitang College of North China University of Science and Technology. Her current research interests include applied linguistics, cognitive linguistics and college English teaching. (email: mingli 1019@126.com).

This work was supported by Hebei Province College English Teaching Reform Project "A Study on Post-CET4 College English Teaching Model Based on Intercultural Communication" (2014YYJG300); North China University of Science and Technology, Education and Teaching Reform Project, "A Study on Intercultural Communication Competence of English Teachers from Independent College" (2015, Y1578-40). Submitted 16 July 2016. Published as resubmitted by the authors 26 August 2016. 